https://helda.helsinki.fi

\title{
Access to Secondary Education (Finland)
}

\section{Kalalahti, Mira}

Bloomsbury Publishing

2019-12-02

Kalalahti , M 2019 , Access to Secondary Education (Finland) . in J Kauko (ed.),

Bloomsbury Education and Childhood Studies : Articles . Bloomsbury Publishing , London . https://doi.org/10.5040/9

http://hdl.handle.net/10138/314616

https://doi.org/10.5040/9781350996281.0019

acceptedVersion

Downloaded from Helda, University of Helsinki institutional repository.

This is an electronic reprint of the original article.

This reprint may differ from the original in pagination and typographic detail.

Please cite the original version. 


\title{
Access to Secondary education (Finland)
}

\author{
Mira Kalalahti
}

\section{Keywords}

Basic education, General upper secondary education, Vocational education, Joint application system, Selective classes

\section{Glossary terms}

Basic education: Basic education in Finland takes place in a comprehensive school. It comprises nine years and caters for all those aged between 7 and 16 years (ISCED 1 and 2). Schools do not select their students. Every student is allocated a place in a nearby school, but they can also choose another school, with certain restrictions. (FNAE 2018a.)

Vocational education and training (VET): After compulsory basic education, school-leavers can opt for general or vocational upper secondary education (ISCED 3). Both forms usually take three years and provide eligibility for entry to higher education. Vocational qualifications can be completed in upper secondary VET, apprenticeship training or as competence-based qualifications. Most young learners complete their upper secondary vocational qualifications at vocational institutions. Competence-based qualifications are usually completed by adults. (FNAE 2018b.)

The Youth Guarantee is a commitment by all EU Member States to ensure that all young people under the age of 25 years receive a good quality offer of employment, continued education, apprenticeship and traineeship within a period of four months of becoming unemployed or leaving formal education (European Comission 2019).

General upper secondary education: After compulsory basic education, school-leavers opt for general or vocational upper secondary education (ISCED 3). Both forms usually take three years and provide eligibility for entry to higher education. General upper secondary education provides students with extensive general knowledge and the readiness to begin studies at a university, a university of applied sciences and vocational training based on the general upper secondary education syllabus. On completion of general upper secondary school studies, students take the Finnish national matriculation examination. (Ministry of Education and Culture 2018a.)

Joint application system: The application for entry to upper secondary schools, both general and vocational, takes place through the joint application system. The selection of students for upper secondary school is based on their grade point average in the basic education certificate. Entrance and aptitude tests may also be used, and students may be awarded points for hobbies and other relevant activities. (Studyinfo.fi 2018a.)

Classes with a special emphasis: Through their elected education boards, municipalities decide on the allocation of lesson hours at schools in their areas. Classes with a special emphasis function as separate streams within regular municipal schools, and they have more lessons (for instance in music, sports, science, languages or art) than the National Core Curriculum requires. (Varjo, Kalalahti \& Silvennoinen 2014.)

\section{Text of the article}




\section{Research on access and equity}

Lower secondary education consists of the three final years of compulsory basic education (ISCED 2). All children are allocated to a local, usually municipal schools. Under the Basic Education Act, local authorities have a statutory duty to organize comprehensive school education for all children. Children may also be taught at home. Every child who is a permanent resident of Finland is obligated to attend lower secondary education as a part of the compulsory education.

Almost all children complete the basic education syllabus. Fewer than 1 per cent of students drop out of compulsory education or leave comprehensive school without having been awarded a leaving certificate (OSF 2018). If the child is unable to complete the objectives of basic education within the allocated nine years due to disability or illness, the child may attend extended compulsory education. Extended compulsory education begins the calendar year a child turns six and lasts for 11 years.

Basic education may include an extra voluntary year of additional studies (year 10) and students can participate in preparatory education for vocational upper secondary education and training (VALMA) or for preparatory education for the work force and independent living (TELMA).

Students mainly continue their studies after completing basic education: approximately 5.0 per cent of the students do not resume studies in education leading to a degree or other qualification. Dropout rates are higher among vocational upper secondary education (6.5 per cent), compared with upper secondary general education (1.4 per cent) and among men (5.8 per cent, compared with women 4.2 per cent). As a general trend, the proportion of discontinuation is declining. (Statistics Finland 2018.)

\section{Demographics}

Pupils begin lower secondary education when they have completed the $6^{\text {th }}$ grade of basic education (approximately 12-13 years). Lower secondary education is compulsory, and the parents and guardians of pupils are responsible for ensuring the pupils complete their compulsory education. Families are directed to social services if a child does not participate in basic education. Pupils have the right to receive enough support to assist in learning and in school attendance as soon as the need for support is detected.

Upper secondary education (ISCED 3 ) is voluntary. If a student does not get a study place during the joint application, he/she will be guided to study counsellors at their lower secondary schools. Young people are guided through the principles of the Youth Guarantee to help them gain access to education and employment.

\section{Policies and regulations}

Every student is allocated a place in a nearby lower secondary school, but they can also choose another school, with certain restrictions. Schools do not select their students. Local authorities and joint municipal authorities are usually the local education providers and they have a duty to organize lower secondary education. In some cases, it is the state or private associations or foundations.

Applying for entry to general upper secondary education or to vocational education and training (VET) is done through either a joint application or a separate application. The Finnish joint application is a national application procedure used by Finnish education institutions when selecting new students for general upper secondary schools, vocational institutions and higher education institutions. (Studyinfo.fi 2018a.) 


\section{Entry and exit}

Every child who is a permanent resident of Finland is obliged to attend compulsory basic education. There is no national examination at the end of the basic education. Nationally sample-based assessments are carried out according to an assessment plan. Compulsory education (primary education and lower secondary education) begins the calendar year a child turns seven and ends when the child has completed the basic education syllabus, or when ten years have passed from the start of their compulsory education (commonly at the end of the academic year pupils turn 17 years). When pupils have completed their education based on the comprehensive school syllabus, they have completed their compulsory education. (Ministry of Education and Culture, 2018b.)

All students are allocated to lower secondary schools. Students can also apply for entry into classes with a special emphasis (on music or arts, for instance) or to any other lower secondary school. Students take aptitude tests to access classes with a special emphasis. Students living in rural areas are commonly allocated to local municipal schools. (Berisha \& Seppänen, 2016; Koivuhovi et al., 2018.)

After compulsory basic education school-leavers opt for general upper secondary education or vocational education and training (ISCED 3). Both forms usually take three years and provide the eligibility to apply for entry to higher education institutions. The selection of students for general upper secondary school is based on their grade point average for the theoretical subjects in the basic education certificate. Entrance and aptitude tests may also be used, and students may be awarded points for hobbies and other relevant activities. The grounds for student admission to education and training leading to a vocational upper secondary qualification are provided by a decree of the Ministry of Education and Culture. These grounds include prior general performance at school, the order of preferences in the application, work experience and gender. Education providers decide whether they will arrange an entrance exam or aptitude test. (FNAE, 2018b.)

On completion of general upper secondary school studies, students take the Finnish national matriculation examination (Ministry of Education and Culture, 2018a). Vocational qualifications can be completed in upper secondary VET, apprenticeship training or as competence-based qualifications (FNAE, 2018b).

\section{Funding}

The Government participates in funding the costs related to general upper secondary education. The State and local authorities participate in covering operating costs as referred to in the Act on the Financing of Educational and Cultural Provision (1705/2009). Financing is allocated on an imputed basis according to the number of students and a unit price determined per student.

Vocational institutions providing upper secondary and further vocational education and training form the framework of the VET providers' network. VET is funded through the Ministry of Education and Culture's budget. The central and local governments both provide portions of the funding of vocational upper secondary qualifications while further and specialist vocational qualifications are funded by the central government. (Ministry of Education and Culture, 2018a.)

For the pupils, lower secondary education is free of charge. Additionally, pupils are provided with a warm meal every day at school and some schools provide extra snacks funded through parents' additional payments. Offsite activities should be free of charge, but parental associations can contribute to them financially. There are no school uniforms. (Ministry of Education and Culture, 2018b.) 
General upper secondary education is free of charge. However, a fee may be charged for some subject studies and for the Finnish matriculation examination. Completing a vocational upper secondary qualification as well as associated education and training, including preparatory training, is free of charge for the students. It is possible to charge students a reasonable fee for training that prepares them for further and specialist vocational qualifications as well as for other vocational further education and training. School meals are free of charge, and students are eligible for reimbursement for travels costs. (Ministry of Education and Culture, 2018a,c.)

Upper secondary students have different streams of financial aid. The ministry develops the student financial aid system according to educational policy objectives and drafts the necessary legislative proposals and the budget for parliamentary approval. (Ministry of Education and Culture, 2018d.)

\section{Teacher quality}

As a rule, teachers have completed a master's degree at a university. The qualifications of the school head and teaching staff are prescribed in the Teaching Qualifications Decree. According to a teacher survey study (Kumpulainen 2017) approximately 96 per cent of the basic education teachers, 99 per cent of the general upper secondary education and 92 per cent of the vocational upper secondary education and training teachers are formally qualified. Generally, the proportion of qualified teachers is rising. There is shortage in special education, where only 87 per cent of the teachers are qualified. (Paronen \& Lappi 2018, 19-20.) The proportion of qualified teachers vary more within vocational education. Geographical variance is small, although shortages of qualified teachers are slightly higher in the southern, highly-populated parts of Finland. (Kumpulainen 2017, 178, 180.)

\section{Instructional materials and resources}

Teaching and teaching equipment are available to pupils free of charge in lower secondary education (basic education). In the general upper secondary schools, textbooks and teaching materials are not free of charge. The students are responsible for covering the cost of these. Students in vocational upper secondary education and training also pay for some of the materials they need, including textbooks, tools, equipment and materials for their own use during and after training.

\section{Transitions}

Both forms of upper secondary education (general and vocational education) provide eligibility for entry to higher education programs. As with upper secondary education, higher education has a binary structure. Higher education is provided by universities and universities of applied sciences. Universities emphasize scholarly research and instruction, whereas universities of applied sciences adopt a more practical approach. Each university and field of study decides their own student selection criteria. Most commonly these include success in the matriculation examination and entrance tests. Higher education institutions have a joint application system, and students can accept only one study place in education that begins in the same academic term. (Studyinfo.fi, 2018b.)

\section{Further reading and online resources}

European Commission (2019), The Youth Guarantee, https://ec.europa.eu/social/main.jsp?catld=1079 [accessed 22 February 2019]

FNAE (The Finnish National Agency for Education) (2017), Finnish Education in a nutshell. Helsinki: The Finnish National Agency for Education, 
https://www.oph.fi/download/146428_Finnish_Education_in_a_Nutshell.pdf [accessed 14 October 2018].

Law 628/1998. Basic Education Act. Available online

https://www.oph.fi/english/education system/basic education [accessed 6 December 2018.]

Ministry of Education and Culture (2018b). Basic education. Helsinki: Ministry of Education and Culture. https://minedu.fi/en/basic-education [accessed 6 December 2018].

Studyinfo.fi (2018a), Finnish application system. Helsinki: Finnish national Agency for Education, Ministry of Education and Culture. https://studyinfo.fi/wp2/en/valintojen-tuki/finnish-applicationsystem/ [accessed 6 December 2018].

Studyinfo.fi (2018b), Higher Education. Helsinki: Finnish national Agency for Education, Ministry of Education and Culture. https://studyinfo.fi/wp2/en/higher-education/ [accessed 6 December 2018].

\section{References}

Berisha, A.-K. and P. Seppänen (2016), 'Pupil selection segments urban comprehensive schooling in Finland: composition of school classes in pupils' school performance, gender, and ethnicity', Scandinavian Journal of Educational Research, (61)2, 240-254.

FNAE (The Finnish National Agency for Education) (2018a), Basic Education. Helsinki: The Finnish National Agency for Education,

https://www.oph.fi/english/education_system/basic_education [accessed 14 December 2018].

FNAE (The Finnish National Agency for Education) (2018b), Upper secondary education and training. Helsinki: The Finnish National Agency for Education, https://www.oph.fi/english/education system/upper secondary education and training [accessed 14 December 2018].

Koivuhovi, S., M.-P. Vainikainen, M. Kalalahti and M. Niemivirta (2018), 'Changes in Children's Agency Beliefs and Control Expectancy in Classes with and without a Special Emphasis in Finland from Grade Four to Grade Six', Scandinavian Journal of Educational Research. Published online 30 Nov 2017. DOI: 10.1080/00313831.2017.1402364.

Kumpulainen, T. (2017) (ed.), Opettajat ja rehtorit Suomessa 2016 [Teachers and principals in Finland 2016]. Helsinki: The Finnish National Agency for Education.

Ministry of Education and Culture (2018a), General upper secondary education. Helsinki: Ministry of Eudcation and Culture. https://minedu.fi/en/general-upper-secondary-education [accessed 14 December 2018].

Ministry of Education and Culture (2018c), Qualifications and studies in vocational education and training. Helsinki: Ministry of Education and Culture. https://minedu.fi/en/qualifications-andstudies_vet [accessed 22 February 2019]. 
Ministry of Education and Culture (2018d), Student financial aid. Helsinki: Ministry of Education and Culture. https://minedu.fi/en/student-financial-aid [accessed 22 February 2019].

Paronen, P. and O. Lappi (2018), Finnish teachers and principals in figures. Reports and surveys 2018:4. Helsinki: Finnish National Agency for Education.

Official Statistics of Finland (OSF) (2018), Discontinuation of education [e-publication]. Helsinki: Statistics Finland. http://www.stat.fi/til/kkesk/2016/kkesk 2016 2018-03-14 tie 001 en.html [accessed 6 December 2018].

Studyinfo.fi (2018a), Finnish application system. Helsinki: Finnish national Agency for Education, Ministry of Education and Culture. https://studyinfo.fi/wp2/en/valintojen-tuki/finnish-applicationsystem/ [accessed 6 December 2018].

Varjo, J., M, Kalalahti \& H. Silvennoinen (2014), 'Families, school choice and democratic iterations on the Right to Education and Freedom of Education in Finnish municipalities'. Journal of School Choice, 8(1): 20-48. 